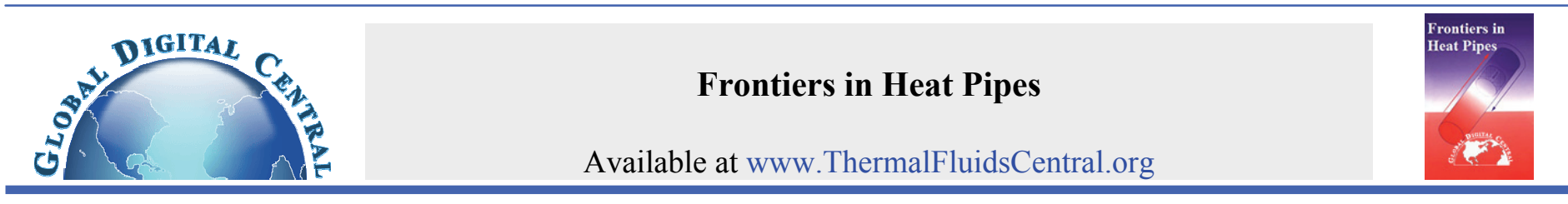

\title{
THE STUDY OF EVACUATED SOLAR COLLECTOR USING PULSATING HEAT PIPE
}

\author{
Jong Soo Kim ${ }^{\mathrm{a}}$, Soo Jung Ha ${ }^{\mathrm{a}}$, Sang Il Lee ${ }^{\mathrm{a}, *}$, Bang Ho Jeong ${ }^{\mathrm{b}}$ \\ ${ }^{a}$ Department of Refrigeration and Air-Conditioning Engineering, Pukyong National University, Nam-gu, Busan, 608-739, Republic of Korea \\ ${ }^{b}$ Kyungunbeomyang Energy Co., LTD., Gangseo-gu, Busan, 618-280, Republic of Korea
}

\begin{abstract}
Solar heat energy, one of the typical renewable energy absorbs radiation energy from the sun and converts it into heat energy. Since it is sustainable and eco-friendly, it can be a good alternative to solve the problem of the depletion of fossil fuels. But it has low density. So, solar collector is very important to use more efficiently. From the viewpoint of low cost as well as short construction schedule for the manufacturing of heat exchanger, flexibility, and high performance, Pulsating Heat Pipe (PHP) draws special attention. Therefore, we use PHP for increasing efficiency of solar collector. In this study, we applied two types PHP to solar collector. One is U type, and other is Double U type. We made evaporating section of PHP by using a ' $U$ ' shape to prevent flooding which is the problem of conventional 'I' type heat pipe of solar collector. Condensing section of PHP was double tube which has the circular finned water tube inside for increasing heat transfer area. PHP was charged R-141b about $100 \%$ of evaporating section volume. And then, we compare the solar collector efficiency according to the evaporating section shape of the PHP on standard water flow rate. Consequently, heat collector efficiency of the $U$ type solar collector is about $15 \%$ higher than Double U type solar collector. And both solar collector works reliably on the standard water flow rate.
\end{abstract}

Keywords: Pulsating heat pipe, Evacuated solar collector, U type solar collector, Double U type solar collector

\section{INTRODUCTION}

Solar energy, one of typical renewable energy absorbs radiation energy from the sun and converts it into heat energy. Since it is sustainable and eco-friendly, it can be a good alternative to solve the problem of the depletion of fossil fuels. But it has low density. So many studies about high efficiency solar collector have been carried out (Morrison et al., 2004; Dhariwal and Mirdha, 2005; Zambolin and Del Col, 2010). There are many types of the solar collector such as flat-plate collectors, stationary compound parabolic collectors and evacuated solar collectors. Among them, since conventional simple flat-plate solar collectors were developed for use in sunny and warm climates, their performance are greatly reduced when conditions become unfavorable during cold, cloudy, and windy days. However, evacuated solar collectors use a vacuum-sealed tube which reduces convection and conduction losses, so the collectors can operate at higher temperatures than flat-plate collectors. And their efficiency is higher at low incidence angles. This effect tends to give evacuated solar collectors an advantage over flatplate collectors in terms of daylong performance.

Evacuated solar collectors use liquid-vapor phase change materials to transfer heat at high efficiency. These collectors feature a heat pipe (a highly efficient thermal conductor) placed inside a vacuum-sealed tube. The heat pipe contains a small amount of fluid that undergoes an evaporating-condensing cycle. In this cycle, solar heat evaporates the liquid and the vapor travels to the heat sink region, where it condenses and releases its latent heat. The condensed fluid returns to the solar collector and the process is repeated (Terpstra and Van Veen, 1987; Kalogirou, 2009).
Conventional heat pipe which applied to evacuated solar collector has very long 'I' type single tube evaporating section. And condensing section size is very small and located where block the water flow (Azard, 2008; Bin et al., 2013) as shown in Fig. 1. In the conventional type, since the working fluids inside evaporating section run to only one direction, when the sunshine is high, it became the cause of flooding lead to dryout. If flooding effect occurred, heat pipe performance was limited (Japan Association for Heat Pipe, 2001). Also the condensing section is very small, so its heat transfer area is not enough. And pressure drop is increased because it located where prevent the water flow (Kreith and Bohn, 2002; Cengel and Ghajar, 2012).

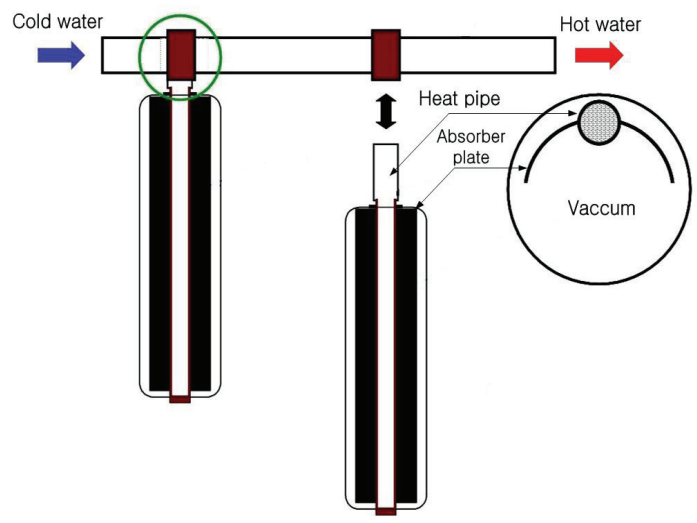

Fig. 1 Conventional 'I' type heat pipe solar collector

\footnotetext{
* Corresponding author.Email: darksia77@pknu.ac.kr
} 
Our evacuated solar collector compensated the defect of conventional heat pipe solar collector. We used pulsating heat pipe (PHP) which has ' $U$ ' type evaporating section to prevent flooding by oscillating and irregular flow of vapor bubble. In the condensing section, water can flow straight inside the water tube without resistance by condensing section of PHP (compare the Fig. 1). Accordingly, pressure drop inside the water tube and water pump power are reduced. In addition, since the heat exchange is occurred on outer surface of water tube unlike conventional 'I' type heat pipe solar collector, heat transfer area of condensing section is increased by a fin that is attached to the outer surface of the water tube.

In this study, we applied two types PHP to solar collector. All of heat pipe have same condensing section shape, but evaporating section is different. One is the U type PHP and other is the Double U type PHP which has two $U$ tube evaporating section. Using these solar collectors, we evaluate each solar collector performance on standard of water flow rate

\section{EXPERIMENTAL DEVICES AND METHODS}

\subsection{Pulsating heat pipe}

A PHP is typically a meandering tube comprised of a serpentine channel with capillary dimension. Initially, the PHP is evacuated and then partially filled with the working fluid. Effects from surface tension cause the formation of liquid slugs interspersed with vapor bubbles. As heat is applied to the evaporating section, the working fluid begins to evaporate. This results in an increase of vapor pressure inside the tube which causes the bubbles in the evaporator zone to grow and pushes the liquid towards the condensing section. As the condensing section cools, the vapor pressure reduces and condensation of bubbles occurs. This process between the evaporating section and condensing section is continuous and results in an oscillating motion within the tube. Heat is transferred through latent heat of the vapor and through sensible heat transported by the liquid slugs (Reay and Kew, 2005). Operating procedure of PHP is shown in Fig. 2.



Fig. 2 Operating principle of PHP

\subsection{Experimental Devices}

Fig. 3 is a schematic diagram of experimental devices. Solar collectors were placed in outdoors where unimpeded area and installed on 35 degree inclination angle to the south with pyrheliomether. Heated water by solar collector was stored at the heat storage tank. And the pump with control valve and stop valve was installed for the flow control. Ttype thermocouple was used to measure the inlet and outlet water temperature.

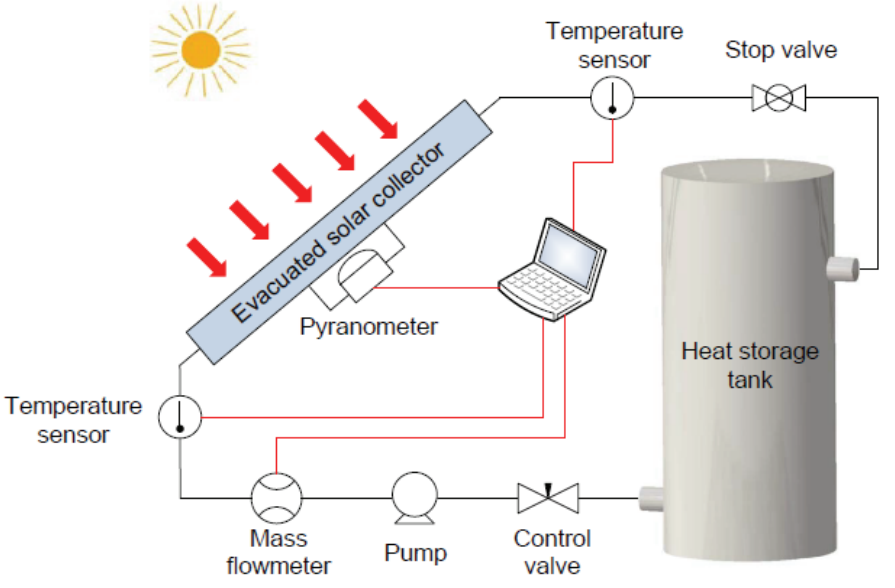

Fig. 3 Schematic diagram of solar collector system

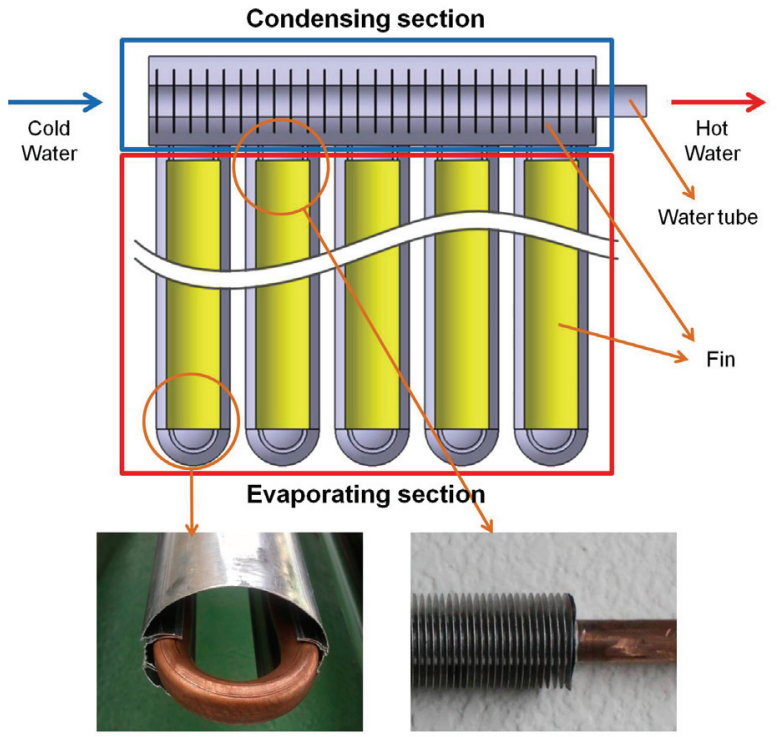

$<$ Shape of the $\mathrm{U}$ tube of PHP and water tube >

Fig. 4 Internal shape of $U$ type solar collector

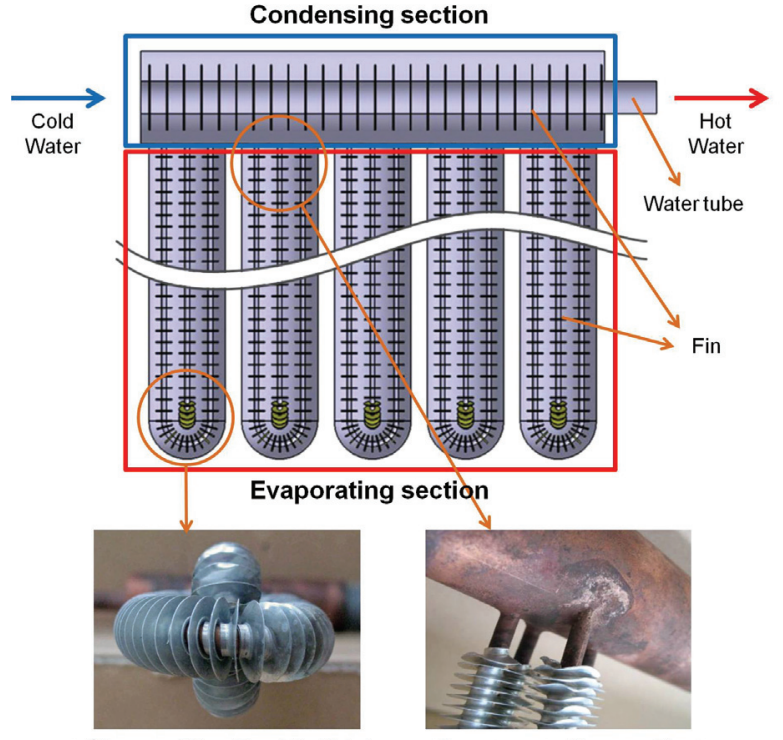

$<$ Shape of the Double $\mathrm{U}$ tube on the evaporating section >

Fig. 5 Internal shape of Double U type solar collector 




Fig. 6 Operating principle of PHP inside the solar collector

Table 1 Specification of the test equipments

\begin{tabular}{|c|c|c|c|}
\hline \multicolumn{2}{|c|}{ Parameter } & \multicolumn{2}{|c|}{ Specification } \\
\hline \multirow{2}{*}{\multicolumn{2}{|c|}{ Collecting Area $\left(\mathrm{A}_{\mathrm{C}}\right)$}} & U type & $1.48 \mathrm{~m}^{2}$ \\
\hline & & Double U type & $1.30 \mathrm{~m}^{2}$ \\
\hline \multicolumn{2}{|c|}{ Storage Tank Volume } & \multicolumn{2}{|c|}{$340 \mathrm{~L}$} \\
\hline \multirow{2}{*}{\multicolumn{2}{|c|}{ Glass concentric evacuated tube }} & U type & $58 \mathrm{~mm}$ \\
\hline & & Double U type & $47 \mathrm{~mm}$ \\
\hline \multicolumn{2}{|c|}{ Selective surface } & \multicolumn{2}{|c|}{ Black chrome coating } \\
\hline \multirow{9}{*}{$\begin{array}{c}\text { U type PHP } \\
\text { *Working fluid: } \\
\text { R-141b }(2000 \mathrm{cc})\end{array}$} & \multirow{4}{*}{$\begin{array}{l}\text { Evaporating } \\
\text { section }\end{array}$} & Length & $1495 \mathrm{~mm}$ \\
\hline & & Pipe(O.D.) & $7.94 \mathrm{~mm}$ \\
\hline & & Pipe(I.D.) & $6.34 \mathrm{~mm}$ \\
\hline & & Fin Diameter & $30.00 \mathrm{~mm}$ \\
\hline & \multirow{5}{*}{$\begin{array}{l}\text { Condensing } \\
\text { section }\end{array}$} & Length & $1165 \mathrm{~mm}$ \\
\hline & & Pipe(O.D.) & $15.88 \mathrm{~mm}$ \\
\hline & & Pipe(I.D.) & $13.84 \mathrm{~mm}$ \\
\hline & & Fin Diameter & $35.40 \mathrm{~mm}$ \\
\hline & & Fin pitch & $2.00 \mathrm{~mm}$ \\
\hline \multirow{10}{*}{$\begin{array}{l}\text { Double U type PHP } \\
\text { *Working fluid: } \\
\text { R-141b (1365cc) }\end{array}$} & \multirow{5}{*}{$\begin{array}{l}\text { Evaporating } \\
\text { section }\end{array}$} & Length (1) & $1560 \mathrm{~mm}$ \\
\hline & & Length (2) & $1382 \mathrm{~mm}$ \\
\hline & & Pipe(O.D.) & $4.76 \mathrm{~mm}$ \\
\hline & & Pipe(I.D.) & $3.60 \mathrm{~mm}$ \\
\hline & & Fin Diameter & $14.65 \mathrm{~mm}$ \\
\hline & \multirow{5}{*}{$\begin{array}{l}\text { Condensing } \\
\text { section }\end{array}$} & Length & $1165 \mathrm{~mm}$ \\
\hline & & Pipe(O.D.) & $15.88 \mathrm{~mm}$ \\
\hline & & Pipe(I.D.) & $13.84 \mathrm{~mm}$ \\
\hline & & Fin pitch & $35.40 \mathrm{~mm}$ \\
\hline & & Fin Diameter & $2.00 \mathrm{~mm}$ \\
\hline
\end{tabular}

In this study, the condensing section of the each PHP is same, but U type solar collector has $21 \mathrm{U}$ tubes and Double U type has 14 Double $\mathrm{U}$ tube as the evaporating section. Spirally-coiled circular aluminum fin was installed on evaporating section of Double U type PHP. Aluminum fin which transfer heat by conduction from inner surface of concentric evacuated tube to PHP was installed on evaporating section of $U$ type PHP. And U type PHP was used more large U tube than Double U type PHP to complement decrease PHP performance due to reduction in numerals of $U$ tube.

Condensing section of PHP was double tube which has the circular aluminum finned water tube inside. The detailed shape and specification of them were shown in Fig. 4, Fig. 5 and Table 1.
Vacuum of PHP could be reached to $0.04 \mathrm{~Pa}$. Working fluid was $\mathrm{R}-141 \mathrm{~b}$ which has high merit number and stability for container from the results of previous research by $100 \%$ of evaporating section volume (Lee et al., 2011). Therefore Double U type PHP was charged by $1365 \mathrm{cc}$ and U type PHP was charged by $2000 \mathrm{cc}$.

Fig. 6 is operating principle of the solar collector using the PHP. If working fluid within heat pipe is vaporized in evaporating section, phase change occurred and vapor bubbles are generated. This vapor bubbles are forwarded to condensing section and heat exchange occur between water pipe and working fluid. After this heat exchange, condensed working fluid is moved to evaporating section. Working fluid transfers heat repeating this process.

\subsection{Experimental Method}

The experiment was conducted from 11 a.m. to 3 p.m. on sunny days. Water was supplied by $1 \mathrm{~kg} / \mathrm{min}$ and $2 \mathrm{~kg} / \mathrm{min}$ according to Standard of renewable energy facilities $(1.2 \mathrm{~kg} / \mathrm{min}$ per collector unit area) (Korea Energy Management Corporation (KEMCO), 2009). Data were collected every 2 seconds on the water inlet/outlet temperature, water flow rate and solar irradiance for calculating solar collector efficiency. And then every data were arranged with the time average.

\subsection{Solar Collector Efficiency}

The quantity of heat transferred to the water in the tank can be calculated by water temperature variation, taking into account the water flow rate and its specific heat:

$Q_{w}=\dot{m} c_{p \cdot w}\left(T_{o \cdot w}-T_{i \cdot w}\right)$

The cumulative collection efficiencies $(\eta)$ can be expressed as a ratio of the amount of heat stored in the tank to the total amount of solar energy irradiation on the collector for the same period of time (Rittidech and Wannapakne, 2007):

$$
\eta=\frac{Q_{w}}{A_{C} G_{T}}=\frac{\dot{m} c_{p \cdot w}\left(T_{o \cdot w}-T_{i \cdot w}\right)}{A_{C} G_{T}}=\frac{\dot{m} c_{p \cdot w} \int \Delta T d t}{A_{C} \int G_{T} d t}
$$

\section{RESULTS AND DISCUSSION}

\subsection{Performance analysis according to shape of PHP}

The experiment was conducted sunny day when the solar irradiance was more than $800 \mathrm{~W} / \mathrm{m}^{2}$ and water flow rate was $1 \mathrm{~kg} / \mathrm{min}$. Fig. 7 and Fig. 8 are graphs of the water inlet/outlet temperature and solar irradiance during measuring period. Its average values are shown in Table 2

When the solar irradiance was $903.7 \mathrm{~W} / \mathrm{m}^{2}$, Double U type solar collector was collected heat by $431.9 \mathrm{~W} / \mathrm{m}^{2}$ and $U$ type solar collector was collected heat by $544.9 \mathrm{~W} / \mathrm{m}^{2}$. Consequently, heat collector efficiency of the $U$ type solar collector is about $13 \%$ higher than Double $\mathrm{U}$ type solar collector.

Heat transfer area of evaporating section of PHP is similar to each other (Double U type: $4.27 \mathrm{~m}^{2}$, U type: $4.53 \mathrm{~m}^{2}$ ). But tube diameter of evaporating section of $U$ type PHP is bigger than Double $U$ type. Therefore, although the charging ratio is same to each other as $100 \%$ of evaporating section volume, quantities of working fluid are 1.4 times more than Double U type PHP. Under the same charging ratio, quantity of working fluid is one of factors contributing to determine performance of solar collector. As a result, $U$ type solar collector which has more working fluid has high efficiency compare with Double U type solar collector. 


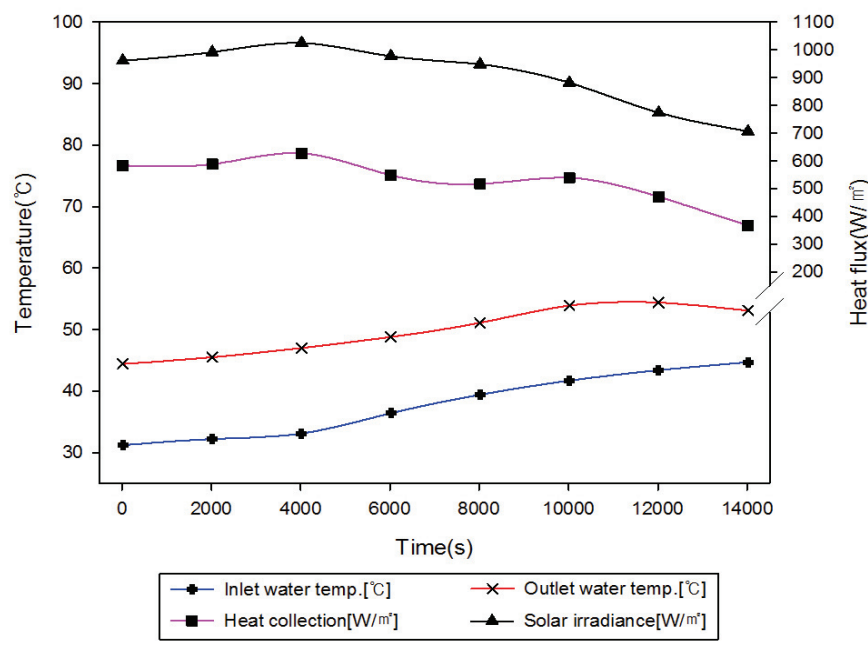

Fig. 7 Profile of water temperature and solar irradiance (U type solar collector, $1 \mathrm{~kg} / \mathrm{min}$ )

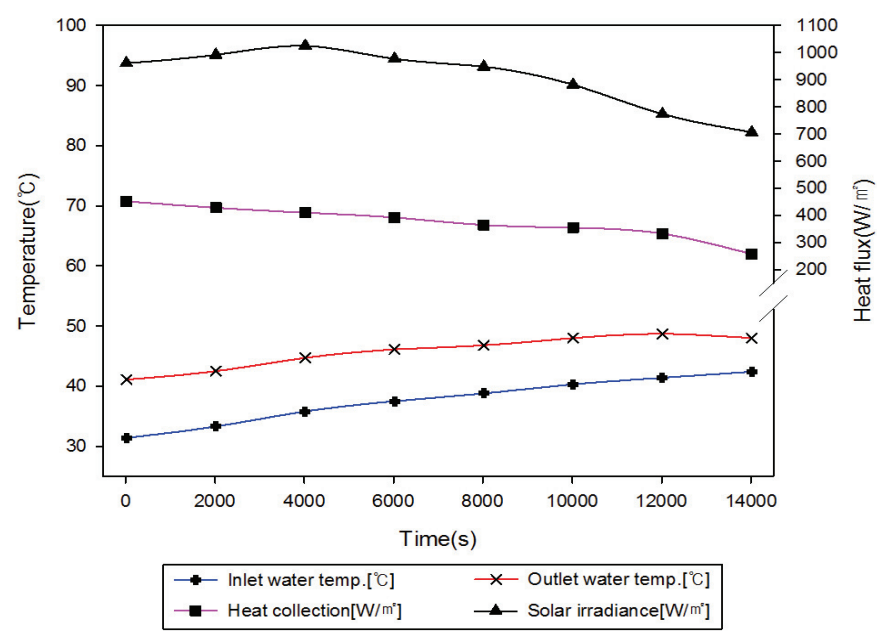

Fig. 8 Profile of water temperature and solar irradiance (Double U type solar collector, $1 \mathrm{~kg} / \mathrm{min}$ )

Table 2 Test results of experiment (Water flow rate: $1 \mathrm{~kg} / \mathrm{min}$ )

\begin{tabular}{|c|c|c|}
\hline Shape of PHP & Utype & Double U type \\
\hline Water flow rate $(\mathrm{kg} / \mathrm{min})$ & 0.94 & 0.97 \\
\hline Water inlet temp. $\left({ }^{\circ} \mathrm{C}\right)$ & 37.9 & 37.8 \\
\hline Water outlet temp. $\left({ }^{\circ} \mathrm{C}\right)$ & 50.2 & 46.1 \\
\hline Ambient temp. $\left({ }^{\circ} \mathrm{C}\right)$ & \multicolumn{2}{|c|}{23.9} \\
\hline Solar irradiance $\left(\mathrm{W} / \mathrm{m}^{2}\right)$ & \multicolumn{2}{|c|}{903.7} \\
\hline Heat collection $\left(\mathrm{W} / \mathrm{m}^{2}\right)$ & 544.9 & 431.9 \\
\hline Efficiency $(\%)$ & 60.3 & 47.8 \\
\hline
\end{tabular}

\subsection{Performance analysis according to water flow rate}

Under the same experimental condition, we measured the performance of solar collector according to the water flow rate. Fig. 9 and Fig. 10 are presented water inlet/outlet temperature and solar irradiance variation when the water flow rate is $2 \mathrm{~kg} / \mathrm{min}$. Its average values are shown in Table 3.

When the solar irradiance was $849.7 \mathrm{~W} / \mathrm{m}^{2}$, Double U type solar

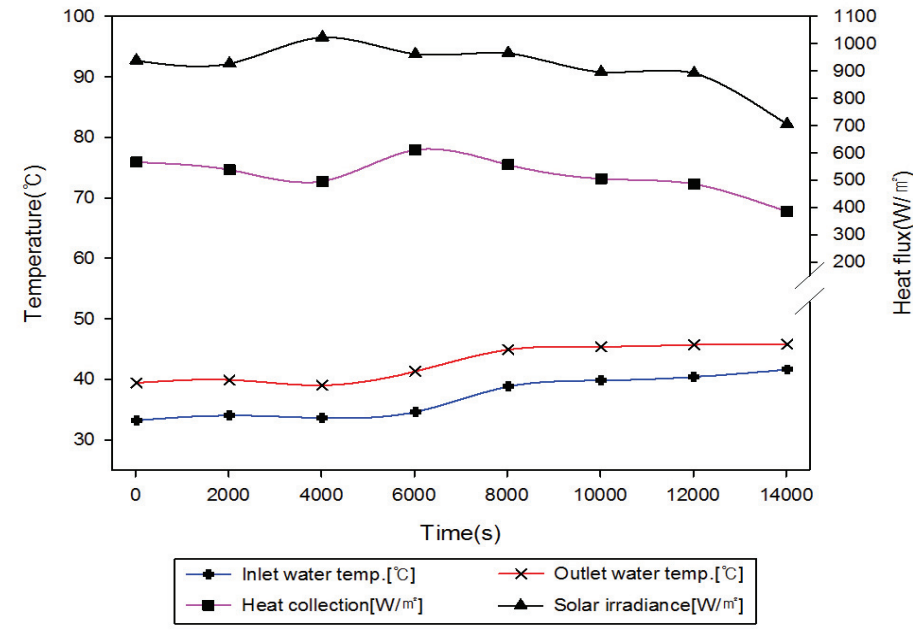

Fig. 9 Profile of water temperature and solar irradiance (U type solar collector, $2 \mathrm{~kg} / \mathrm{min}$ )

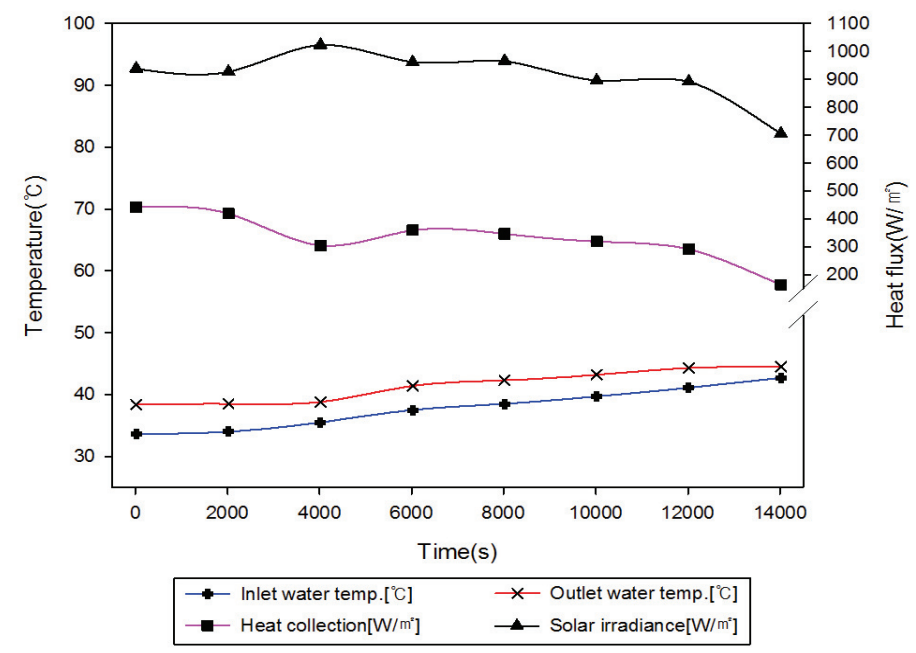

Fig. 10 Profile of water temperature and solar irradiance (Double U type solar collector, $2 \mathrm{~kg} / \mathrm{min}$ )

Table 3 Test results of experiment (Water flow rate: $2 \mathrm{~kg} / \mathrm{min}$ )

\begin{tabular}{|c|c|c|}
\hline Shape of PHP & U type & Double U type \\
\hline Water flow rate $(\mathrm{kg} / \mathrm{min})$ & 1.94 & 1.96 \\
\hline Water inlet temp. $\left({ }^{\circ} \mathrm{C}\right)$ & 37.2 & 37.8 \\
\hline Water outlet temp. $\left({ }^{\circ} \mathrm{C}\right)$ & 42.9 & 41.6 \\
\hline Ambient temp. $\left({ }^{\circ} \mathrm{C}\right)$ & \multicolumn{2}{|c|}{23.5} \\
\hline Solar irradiance $\left(\mathrm{W} / \mathrm{m}^{2}\right)$ & \multicolumn{2}{|c|}{849.7} \\
\hline Heat collection $\left(\mathrm{W} / \mathrm{m}^{2}\right)$ & 520.8 & 397.5 \\
\hline Efficiency $(\%)$ & 61.3 & 46.8 \\
\hline
\end{tabular}

collector was collected heat by $397.5 \mathrm{~W} / \mathrm{m}^{2}$ and $\mathrm{U}$ type solar collector was collected heat by $520.8 \mathrm{~W} / \mathrm{m}^{2}$. Consequently, heat collector efficiency of the $U$ type solar collector is about $15 \%$ higher than Double $\mathrm{U}$ type solar collector. Compared with the results when the water flow rate is $1 \mathrm{~kg} / \mathrm{min}$, although temperature difference between inlet and outlet temperature is lower, solar collector efficiencies are almost equal. As a result, both solar collector works reliably on the standard water flow rate. 


\section{CONCLUSIONS}

In this study, we applied two types PHP to solar collector and evaluate each solar collector performance on the standard water flow rate. The results of the experiment may be summarized as follows:

(i) From Table 3, when the solar irradiance was $849.7 \mathrm{~W} / \mathrm{m}^{2}$, Double U type solar collector collected heat by $397.5 \mathrm{~W} / \mathrm{m}^{2}$ and $U$ type solar collector collected heat by $520.8 \mathrm{~W} / \mathrm{m}^{2}$. Consequently, heat collector efficiency of the $U$ type solar collector is about $15 \%$ higher than Double $U$ type solar collector

(ii) Although both solar collectors have almost same heat transfer area of evaporating section of PHP and charging ratio, the quantities of working fluid of $U$ type PHP are more than Double U type value. Therefore, U type solar collector shows much better performance compared with Double U type solar collector.

(iii) When the water flow rate was increased from $1 \mathrm{~kg} / \mathrm{min}$ to 2 $\mathrm{kg} / \mathrm{min}$, water outlet temperature was decrease. But in each condition, solar collector efficiencies are almost equal in less than $1 \%$. As a result, both solar collector works reliably on the standard water flow rate.

\section{ACKNOWLEDGEMENTS}

This work was supported by the solar heat collecting device using heat pipe of the Korea Institute of Energy Technology Evaluation and Planning (KETEP) grant funded by the Korea government Ministry of Knowledge Economy.

(No. 1677000201100200)

\section{NOMENCLATURE}

$A_{C} \quad$ collecting area $\left(\mathrm{m}^{2}\right)$

$c_{p \cdot w} \quad$ specific heat $(\mathrm{J} / \mathrm{kg} \cdot \mathrm{K})$

$G_{T} \quad$ solar irradiance $\left(\mathrm{W} / \mathrm{m}^{2}\right)$

$\dot{m} \quad$ water flow rate $(\mathrm{kg} / \mathrm{min})$

$T_{i \cdot w} \quad$ water inlet temperature $\left({ }^{\circ} \mathrm{C}\right)$

$T_{o \cdot w} \quad$ water outlet temperature $\left({ }^{\circ} \mathrm{C}\right)$

$Q_{w} \quad$ heat recovery amount of water (W)

$\eta \quad$ solar collector efficiency $(\%)$

\section{REFERENCES}

G. L. Morrison, I. Budihardjo and M. Behnia, 2004, "Water-in-glass evacuated tube solar water heaters", Solar energy, 76, 135-140. http://dx.doi.org/10.1016/j.solener.2003.07.024
S. R. Dhariwal and U. S. Mirdha, 2005, "Analytical Expressions for the Response of Flat-Plate Collector to Various Transient Conditions", Energy Conversion and Management, 46, 1809-1836. http://dx.doi.org/10.1016/j,enconman.2004.08.008

E. Zambolin and D. Del Col, 2010, "Experimental analysis of thermal performance of flat plate and evacuated tube solar collectors in stationary standard and daily conditions", Solar Energy, 84, 1382-1396. http://dx.doi.org/10.1016/j.solener.2010.04.020

M. Terpstra and J. G. Van Veen, 1987, Heat Pipes: Construction and Application, Elsevier Applied Science.

S. A. Kalogirou, 2009, Solar Energy Engineering, Academic Press.

D. A. Reay and P. A. Kew, 2005, Heat pipes, $5^{\text {th }}$ ed., ButterworthHeinemann.

E. Azad, 2008, "Theoretical and experimental investigation of heat pipe solar collector", Experimental Thermal and Fluid Science, 32, 16661672 .

http://dx.doi.org/10.1016/j.enconman.2006.09.021

Bin $\mathrm{Du}$, Eric $\mathrm{Hu}$ and Mohan Kolhe, 2013, “An experimental platform for heat pipe solar collector testing", Renewable and Sustainable Energy Reviews, 17, 119-125

http://dx.doi.org/10.1016/j.rser.2012.09.009

Japan Association for Heat Pipe, 2001, Practical Heat Pipe, $2^{\text {th }}$ ed., The Nikkan Kogyo Shimbun (in Japanese).

F. Kreith and M. S. Bohn, 2002, Principle of Heat Transfer, $6^{\text {th }}$ ed., Thomson Learning.

Y. A. Cengel, and A. J. Ghajar, 2012, Heat and Mass Transfer (Fundamentals and Applications), $4^{\text {th }}$ ed., Mc Graw Hill.

Lee, S. I., Son, G. J., Kim, J. S., Ha, S. J., and Jung, B. H., 2011, "Performance Evaluation of the Evacuated Solar Collector using the Pulsating Heat Pipe", Proceedings of International Heat Pipe Symposium, 196-200.

Korea Energy Management Corporation (KEMCO), 2009, "Standard of Renewable Energy Facilities - Solar Collector" SH-101. http://www.knrec.or.kr/knrec

Rittidech. S., and Wannapakne. S., 2007, "Experimental Study of the Performance of a Solar Collector by Closed-End Oscillating Heat Pipe (CEOHP)", Applied Thermal Engineering, 27, 1978-1985. http://dx.doi.org/10.1016/j.applthermaleng.2006.12.005 